\title{
THE ROLE OF SULTONKHUJA ADO IN THE LITERARY ENVIRONMENT OF KUKAND
}

\author{
Madumarov Utkirbek Sobirjonovich \\ Teacher of Andijan State University, \\ Uzbekistan
}

Article DOI: https://doi.org/10.36713/epra4108

\begin{abstract}
The details of Sultankhuja Ado, a descendant of Khoja Ubaydullah Ahror, are insufficient in the studies of independence and early literary studies. There is no information about his life in the manuscripts of the poet kept in the Institute of Oriental Studies of the Academy of Sciences of the Republic of Uzbekistan.

We can briefly study the life and activity of the poet based on various sources dating from the 18th - 19th century.

In some of the manuscripts we have seen, such as "Samaria” by Abu Tahirhoja, "Tazkiraii Kayiyumi" by P. Kayumiy, "Buyuk ma'naviy murshid" by B.Valihojaev, "Zapiski o Bukharskom Hanstve" by P.Demezon and I.V.Vitkevich, we have read the references in the sources and in the articles of several researchers.

For example, literature scholar E. Shodiev notes that there are poems by the poet in "Bayozi Fakhri Rumoni".

Sheikh-ul-Islam, Khujakalon Sultanhoja Ado was born in Samarkand. But the year of birth is unknown. He received his first religious education from his father Khudoyorbek. He later continued his education at the Kukeldash madrasah in Bukhara. He was one of the leading students of the Madrasah. He was promoted to the rank of the Sheikhul-Islam of Samarkand because of his profound knowledge of religion and deep thoughts.
\end{abstract}

\section{DISCUSSION}

The details of Sultankhuja Ado, a descendant of Khoja Ubaydullah Ahror, are insufficient in the studies of independence and early literary studies. There is no information about his life in the manuscripts of the poet kept in the Institute of Oriental Studies of the Academy of Sciences of the Republic of Uzbekistan.

We can briefly study the life and activity of the poet based on various sources dating from the 18 th - 19th century.

In some of the manuscripts we have seen, such as "Samaria" by Abu Tahirhoja, "Tazkiraii Kayiyumi" by P. Kayumiy, "Buyuk ma'naviy murshid" by B.Valihojaev, "Zapiski o Bukharskom Hanstve" by P.Demezon and I.V.Vitkevich, we have read the references in the sources and in the articles of several researchers.

For example, literature scholar E. Shodiev notes that there are poems by the poet in "Bayozi Fakhri Rumoni".

Sheikh-ul-Islam, Khujakalon Sultanhoja Ado was born in Samarkand. But the year of birth is unknown. He received his first religious education from his father Khudoyorbek. He later continued his education at the Kukeldash madrasah in Bukhara. He was one of the leading students of the Madrasah. He was promoted to the rank of the Sheikh-ul-Islam of Samarkand because of his profound knowledge of religion and deep thoughts.

Unfortunately, we have not come across any reliable information about the later life of the poet, how he came to the palace of Umar Khan. Academician A. Kayumov writes in the book "Kokand literary environment" (Qo'qon adabiy muhiti): "Ado had always performed important tasks with the khan and his relations with other countries which are noted in "Munatahab ut-tavorih". For example, he took part in the war between the governor of Bukhara, Shahmurodbiy and Khudayarbiy the governor of Uratepah before 1212 $\mathrm{AH} / 1797$ - $1798 \mathrm{CE}$ and he was in the side of Shahmurodbiy. Hence Ado was in the service of Shahmurodbiy the governor of Bukhara during the time being. The same year, Shahmurodbi died and his son Amir Haidar succeeded him to the throne of Bukhara. During the reign of the Emir, Sultan Khoja Ado should have changed his workplace to be in the service of the Kokand khanate. Later, the brother of Amir Haidarbek also fled to Kokand and took refuge 
in Umarhon. However, Ado must have come to Kokand before the reign of Umarkhan (1811). When Umar Khan got to the throne, he sent an envoy and tried to establish a friendly relationship with the Emir of Bukhara. Among the ambassadors was Sultankhoja Ado ${ }^{1}$.

"He (Amir Umarkhan is meant U.M.) got himself named as Amir al-Mu'minin and made a sermon on his own name, got coins to be produced and wearing the crown of kingship sat on the throne of the land... And he distributed the positions of acts that of Genghis Khan. Therefore, ishan Turakhuja makhdumi a'zam and Sulrankhuja Akhroriy were treated with the rank of kalon, my dear, his highness, was assigned with the rank of Shekh-ul Islam, I was assigned with the rank of naqib (inspector) for the sake of sympathy and compassion though I was young ${ }^{2}$.

"The History of Shahrukhiy" (Tarikhi Shohrukhiy) states that "... the ruler of the Shari'ah has always acted as a scholar (truth seeker) in the assembly of the Emir (Umar Khan - U.M)", - and the names of several religion leaders with high ranks, such as Zakirhoja ishan, mullah Mirzo Kalon, mullah Muminjon Mawlavi, Sultonkhuja Akhroriy, Mahmudhon tura Ahroriy, Ma'sumkhan and Jahongirkhon tura have been mentioned.

Such information is also found in Mirza Olim Mahdum Haji's "History Turkestan" (Tarikhi Turkiston). In this work, the author says that Sultankhuja Ahroriy was always in conversation with the Emir, and that whenever any of the royal orders was referred to the scholars, such as Omar Khan Sultankhuja Ado, to introduce Sharia rules.

Gulhani metions Ado in his "Zarbulmasal" along with others to be one of those wise and modest.

Qadi Rahmatullah Wozeh's memoir "Tuhfat ul-ahbob" quotes Ado to be the malik-ul kalam, the leader of the virtues, and the descendant of Hoja Ubaydullah Ahror.

Ibrat's book "The History of Fergana (Farg'ona tarixi) " reads: "In this Paradise Age (referring to Amir Umarhan - U.M) there are interlocutor and wise scholars, such as, Zokirkhuja Ishan, Sheikh ul-Islam Namangoniy, Mavlaviy Namangoniy... Ishokbek Tura, Sultonkhontura..., all kinds of issues and verdicts concerning the kingdom are adhered to their fatwas".

There is an episode close to this one in Mirza Karim's novel "Mohlaroyim". It mentions that Amir

\footnotetext{
${ }^{1}$ Қаюмов А., Қўқон адабий мухити, Т.: 1961 й. 60-

б. (Kayumov A., The literary environment of Kukand, T.: 1961. p 60.

${ }^{2}$ Мухаммад Хакимхон, Мунтахаб-ут таворих. Т.: “Янги аср авлоди", 2010 йил. 346-б. (Muhammad Hakim Khan, Muntahab-ut tavorih. T.: "Generation of the New Age," 2010. 346 p.)
}

Umar Khan ruled his land with a sympathetic companion like Mohlaroyim, his minister such as Kalon Ismatullabi, Sheikh al-Islam Ma'sumkhan tura, khujakalon Sultanhontura and Mawlana Abdulkarim Fazli all of which have got good intentions and are wise men ready to share the grief of nation with that of their own.

In total, there are more than 10 places in the roman mentioning Sultanhoja Ado. In almost every case the author paid attention to him being close to Amir Umar Khan, being well-known for his pious and composing good quality poets.

In "Mohlaroyim" Sultankhon Ado's laughing out loud at Amir's clawn's funny acts ; a separate tent being made for Sultankhuja after the hunt; he having meal with Emir scenes are not left unnoticed by the reader as well. The fondness of both Uvaysi and Nadira to the ghazals by Ado are also shown in the work. In a conversation with Nadira, Uvaysi gets excited talking about the fact that Fazli and Ado wrote wonderful ghazals that there was no way one could not be amazed, as if both scholars were still unmanned treasure. She says that the more she listens to his works, the more they seem sweeter. Nodira replied:

- "The water flowing in front of you is worthless, bibi!" - Nodira says.

And she thinks to herself, "There is at least some meaning in Jahon otin being jealous. Mevlana Sultankhuja has spent most of his time with the Emir, became well-known with the position of khujakalon, a very clean and strong Islamic cleric, he was strong in faith into Islam, so he was a trusted man of His Majesty Amir Umar Khan. He resonated pencil In both Persian and Turkish, and many musicians composed songs to his ghazals, and the singers used to sing those songs non-stop... "(p. 130).

On one of the pages of " Davr Nodirasi" there is a picture as follows: "Umarkhan... acted on the advice of the nobles, wise and scholars. On this occasion as well, Is'hokkhantura, Sultonkhontura, Ma'sumkhontura, Ishankhantura, Jahongirtura, Said ofoqiy released their fatwa on approval of the khan's conquest to Oratepa. "(p. 63).

Sultonkhuja Ado was one of the trusted people of the Emir and was in the service of the khan, he also took part in several battles. In particular, he participated in the march to Oratepah and the siege of Jizzakh. "Sayyids Ishan Turakhojai Khoja kalon, Sultankhonkhojai Khoja kalon, my beloved, His Highness, Sheikh-ul-Islam ... stand in the shadow of the high royal heights of the kingdom and aim to crush and shower the enemy."3

\footnotetext{
${ }^{3}$ Мухаммад Хакимхон, Мунтахаб-ут таворих. Т.: “Янги аср авлоди”, 2010 йил. 375-б. (Muhammad Hakimkhan, Muntahab-ut-tavorih. T.: "New century generation", 2010, p.375)
} 
This book also tells the story of Amir Umarhon's marriage to Sultankhan Ado's daughter. According to the story, an official named Sayyid Mahmudkhan was ready to do anything to please Amir Umarkhan and to ask the Emir to appoint himself as a governor to somewhere. In particular, he tells the khan that Sultankhudja had a daughter unmatched in beauty. He repeatedly insists that she should be brought to the Khan under any circumstance.

This episode was illustrated in the book ${ }^{4}$ "Jinlar Bazmi (The Party of Jinns)" by A.Ismoil in a fictional way.

According to the story, Amir Omaron, despite his marrige to Mohlaroyim, married to Sayyid Ghazikhoja's daughter Oyposhsha (according to Muntahab ut-Tavorih, the girl's name is not Oyposhsha, but Khonposhsha U.M). Mohlaroyim sought a third wife for Amir Umarkhon in order to inform Oyposhsha of how the daily life would be after her husband is married to another woman. In other words, "the first lady of the harem changed from sayyid to sayyod in this case. Oyposhsha was not the daughter of a bek (a rank lower than khuja) as Mohlaroyim, but she was one of those "khujaqizs" (The daughter of a khuja) with higher ranking as she was a descendant of khuja origin. What could be more "nobility" in her - she was not the descendant of khuja who were descendants of Caliphs, she was a daughter of sayyid or tura who were descendants of the Prophet. There were many old women around the harem. Two of these were called for a service, they found a girl whose origin was never mixed with those of commoners, the daughter of Sulton Khojai-kalon, who was sitting behind the chastity curtain. The girl was the silk thread of Sayyid origin in both paternal and maternal side, she was Ahroriy from father's side , and she was the fruit of Mahdumi Azami family tree, she was such marvelously beautiful that she even charged the moon for her beauty. The first lady of the

\footnotetext{
${ }^{4}$ Асар Абдулла Қодирий умрининг сўнгги йиллари, унинг қамалиши билан боғлиқ воқеаларга бағишланган. Сюжет хам шунинг устига қурилган. Ёзувчи Қодирийнинг “Амир Умархон канизи” номли асар ёзмоқчи бўлганини, қатор фактлар тўплаганини қиссага мохирлик билан киритган. Таъбир жоиз бўлса, Қодирий тилидан “Амир Умархон канизи”ни ёзган. (Тhe work is devoted to the last years of Abdulla Kodiriy's life, events related to his imprisonment. The plot is also built on that. The writer skillfully included in the story that Kadiri wanted to write a book entitled "Amir Umarxon Kanizi (The Concubine of Emir Umarkhan)" and collected a number of facts. It can be noted that he wrote "Amir Umarxon Kanizi" from Kadiriy's tongue.)
}

harem struggled to seek to convey the description of that Sayyida to the ears of the Amir al-Muslimin".

The girl whose description has been given above is named Zubayda poshsha (the name of the girl is not mentioned in "Muntahab ut-Tavorih" U.M.) As mentioned earlier, she is the daughter of Ishan Sultanhodja.

At that time, one of the Sayyids, Mahmudkhontura, visited the palace of Amir Umarkhan almost daily in his desire to rule Uratepa. His desire for the power of Oratepa through his wife, Sayyid Mahmud, was brought to light by the fact that Ishan Sultankhuja had to settle for the marriage of his virgin daughter to the Amir-al-Muslimin. Of course, at the beginning of this work, was Mohlarayim.

In his next visit to the Khan, Sayyid Mahmudkhon described the importance of connecting the Amir-ul Muslim family with the Prophet's family in his frequent and low-pitched tone like this, "Our Lord has made this world perfect for you. Now, if you want to be one of the beloved of God in the hereafter, you should also consider take measures for that." . He spoke very slowly, as if it were his secret being shared. It's like, "I wouldn't tell another person, but you ..." Sayyid Mahmudkhon going on to say that the relationship and the purpose of this relationship are compatible with the rank of the Amir-ulMusilimin. In short, Sayyid Mahmud Khan persuades the king to take her as a second wife.

Images related to the poet give a more complete picture in this very place. Because, according to a tradition still kept by the Uzbek people, Sayyid does not wed their daughter to a commoner. That is why Sultankhuja refused to wed his daughter to Amir Umarkhan.

Other prominent Sayyids were also informed and dissatisfied. In particular, Turakhuja khujakalon and Ma'sumkhon tura come to the khan and try to dissuade him. In particular, they advised that no khan or prince had done such a stupid act before Umarkhon even when they did so, the outcomes were not for good. In particular, the Masumkhon tura says: "It is better to wash your hands with your own blood than to stretch forth the hands to the Prophet dynasty." The Khan said that he had no intention of doing this, and that everything started from Mahmudkhan, that he had taken a promise from the khan. These great Sayyids visit Sultankhuja. Sultankhuja also insists that Mahmudkhon received a promise. So, for the sake of the promise, the wedding will not be ruined. However, not long after the wedding, the khan became seriously ill and died.

Even during the reign of Muhammad Ali Khan Sultanhoja Ado remained one of the most respected people in the khanate. Of course, Sultankhuja would be among the ambassadors sent to other countries.

Muhammad Alikhan seeks advice from the Sultankhuja on various issues. For example, when 
Amir Nasrullah's brother, Umarhon, escaped from his brother to Margilan, Muhammad Alikhan wanted to bring one of the common people to his service. However, Sultankhuja Ado insisted that Umarkhan was the prince of Bukhara, and advised to send Sultan Mahmudkhon (brother of Muhammad Alikhan) to meet. The Khan accepts this.

"Amir Nasrullah ... In 1243 AH / 1827-28

CE, Emir Narsulloh begged for sending, His highness, Ishan Sultonkhon (Ado) from Muhammadalikhon to Bukhara and praised him with the title of Sheikh-ul-Islam of Bukhara ${ }^{5 "}$

Sultankhuja was a precious person to Amir Nasrullah. Ado did not get even less honor in Bukhara than Kokand. He was respected not only in Bukhara but throughout the country. The following incident confirms this.

Amir Nasrullah attacked Jizzakh fortress. Being sieged, Emir Muhammadrahim Devonbegi and other Emirs asked Sultonkhuja to be sent into the fortress for truce, Emir agreed: "We leave the ark fortress only when the master Ishan Sultankhan khujai Sheikh ul-Islam becomes in-between and promises to be in charge of the truce issues." 6

The fact that Ado was a respected and influential figure in the Kokand Khanate and the Bukhara Emirate can be found in written sources reflecting that time. But the literature we have seen so far contains the above.

The insufficient amount of material related to the poet's biography was not sufficient to examine his personality. His birth date is unknown, but his death date is stamped in the books. But they are different. For example, in the "Samaria" of Abu Tahirhoja, we read that the tomb of Sheikh-ul-Islam Sultonkhan Ado was to the south of the Khoja Ahror mausoleum in Samarkand and died in Bukhara in $1251^{7} \mathrm{AH}$

Sadriddin Aini in "Namunayi Adabiyoti Tajik (Examples from Tajik Literature)" refers to the death of Sultonkhuja Ado as Bukhara in $1252 \mathrm{AH}$. He notes that in his poem "Sadly murd Sultankhan" wuold be answered in this regard.

According to the information provided by Qadi Rahmatullah Wozeh's "Tuhfat ul-ahbob" memoir, the poet died in 1250 AH.The date of this year is 1258 AH in "Tazkirayi Qayyum"" by Pulatjon Qayumiy.

\footnotetext{
${ }^{5}$ Мухаммад Хакимхон, Мунтахаб-ут таворих. Т.: “Янги аср авлоди", 2010 йил. 80-б (Muhammad Hakimkhan, Muntahab-ut-tavorih. T.: "New century generation", 2010, p.80)

${ }^{6}$ Мухаммад Хакимхон, Мунтахаб-ут таворих. Т.: “Янги аср авлоди”, 2010 йил. 91-б. (Muhammad Hakimkhan, Muntahab-ut-tavorih. T.: "New century generation", 2010, p.91) ${ }^{7} 1835-36^{\text {th }}$ years of Current Era
}

Muhammad Hakimkhan writes in his book "Muntahab ut-Tavorikh" that Ado had been suffering from fever in 1250 A.D. for eight days, despite the doctors' efforts, he died on Thursday, the 12th of Sunbula month. We believe that this date is closer to reality.

As Pulatjon Kayumiy writes about Ado, he considers that the poet had lived a poor life, no matter how great he was and how great ranks he held.

The poet was one of the members of tariqah in both artistic life and in real life. Sultonkhuja Ado and Naqibkhan Tughral (also descendants of Khoja Ahror, the poet's relatives) contributed to the spread of the Nakshbandiya teaching that was inherited by their forefathers Ahroris. These are the representatives of the chain of tariqah in the late 19th and early 20th centuries.

Ado's creativity was highly valued by his contemporaries. Famous people of his time, such as Fazli, Hoziq, Hakimkhan tura, were in close contact with him.

One of the leading, truthful and right-minded poets of the time, Junaidulla Hoziq notes that there were three famous poets in Kokand in the end of his roman "Yusuf and Zulaikha" and the first of these three talented poets was Ado.

Orientalist Demezon (1807-1873) came to our country in 1834 . He got acquainted with Bukhara and Samarkand, met various people. He wrote a travel report $^{8}$.

In that report, he also covered the information on Sultankhuja Ado. In particular, he said that he had a guest in Ado's house, had a private conversation with him, and was impressed by the Shaikh-ul-Islam. He provided details about the poet that are not found in other sources. In it, Ado is described as a self-respecting, cautious person who does not like flattery. The poet says that he does not approve of the flattery of those around the Emir of Bukhara and neither the deeds of the Emirate. Ado also said he was interested in many sciences, including chemistry, geography and medicine. He had asked curiously from Demezon what were the ideas of French scientist and mentioned that he himself had done some experiments on turning copper into gold. He also wrote about Ado's poetry and poems that made him popular in Turkestan.

The bayoz (a type of memoir) by Abdulkarim Kamiy in 1896 also provides examples of the ghazals of Ado.

The "Tazkirayi Qayyumiy" also contains some information about Sultonhoja Ado. The author of the collection introduces Ado in his first notebook under the number 74. A little earlier (p. 138) it says, "The aristocratic representatives, such as Afsus,

\footnotetext{
${ }^{8}$ This report was published as a book under the name "Zapiski o Bukharskom Hanstve"
} 
Ma'yus, and Ado, surrounded the Khan, not leaving a place to Ma'dan Ghazi." This was the way of introducing poets served at the palace which became a "tradition" of Soviet critics. Accordingly, while writing about Ado the author says, "We cannot even point out him to be among the Uzbek poets, even if he has a few poems in the Uzbek language," and since he had lived in Kokand for several years, the author mentions him as a "guest poet". He further mentions that he had two companions named Khol Boki and Nasriddin (in the sense of servants - U.M). The line "Gar Ado Navoiydan so'zini ..." was explained as a flattery and ass kissing to the khan. After the information about the poet, his rhythmic ghazal "Biri" was provided.

We find positive thoughts about the poet in P.Kayumiy's book "The history and literature of Khokand". The author states that Ado was one of those "great poets" of the poets of the era of Umar Khan, he had been a scholar, and had had many poems, they had provided expressions clearly, comparisons had been clean and had held joyful context. He further comments that although poems like Roziy, Fazliy and even the Umarkhan had the ability that of Ado, Ado had been superior to them.

Sadriddin Ainiy in his "Namunayi Adabiyoti Tajik" said that Sultankhuja Ado had had a deevan in both Turkish and Persian, and in this collection he mentions 3 poems by the poet. They are: "Angusht" rhythmic ghazal, another ghazal starting with "Dilamro hamchu", and rhythmic ghazal "Hanuz". This last ghazal is taken from the memoir "Tuhfat ulahbob" by Qadi Rahmatullah Wozeh. The collection also contains four fards (a type of poetry) of the poet.

"The Anthology of Uzbek Literature" published in 1945, includes three poems by Ado: "Somondin par dema ...", "Ey, ko'z ayla mardumligh ..." and "Karkining shohi kibi ..." ghazals. The career of the poet was often studied in a one-sided way at the Uzbek literature of the former Soviet Union. In particular, Ado was introduced as a representative of feudal-clerical literature. About him and the like: "The great aristocrat and the king's minister, Kasim Beklarbegi Wazir, the great aristocrat and clergyman, the Sheikh-ul-Islam, the" master of the poets" of the Umarkhan palace, had the same class interests. The khans were the head of such groups, the ruling feudal aristocracy, the advocate of the interests of this class, or rather the executor of the class".

Elsewhere, we read: "The peculiarity of these poets' works is that the khanate of Kokand and his Emir Umarkhan were exalted upon to the skies, and he was seen even superior to Hussein Baikara and Babur. Each of the poets of the lofty palace, who was given great pride, thought of himself as "the Nizamiy of Age, the Jami of Time, and the "The Collocutor of Navoiy".

As the Kokand literary circles and its representatives' works were studied in Soviet literary studies, their career, in particular, Sultonkhuja Ado was seen as a representative of an exploiter class and even some absurd words were attached to him and his name.

"Amir Umarkhon gathered many poets around his palace. Many of these poets were such panegyrist and flirtatious poets as Fazli, Nusrat, Ado and Hijlat. These poets wrote poems with rudeness, sang razzle-dazzle in their erotic poems and often wrote lines imitating Amiriy's and each other's poems."

An analysis of the works of Ado and other poets by genres is similar to the above. Their "fault" was that they lived in the palace, wrote poems on mystic topics, and had been descendants of great people like Khoja Ahror Wali."

Ado, Ashurmuhammad Ramziy, Fazliy, Ziynat, and Munshiy, who wrote ghazals with aristocratic pleasure, also ordered the literary people to write works in the genre of devotions, and persuaded them to demagoguery".

More detailed information on Sultonhoja Ado can be found in the book "Kukond adabiy muhiti" by Kokand literary critic Azizkhon Kayumov, published in 1961. Scientist claims that that in any books there was no information about Sultankhuja Ado's childhood, but the only single information was on him being born in Samarkand. As a literary critic goes on to comment on Ado, he sees him as a representative of feudal-clerical literature. That is how he looked at their personality and creativity. He cites Hakimkhan's "Muntahab ut-Tavorikh" as the main source of information about the poet.

Ado has also been the subject of conversations among various literary circles of the 20th century. Said Ahmad's book "Topganlarim va yo'qotganlarim (Findings and Losings)" we can read his memory "Nazm chorrakhasidan reportaj (A Report from Rythm Junction) on Gafur Gulam: "At that time the Bokiy teacher was talking about the Ado, the leading poet in the Umarkhan's Palace, about his four-line poem ending with the line "Ado qaddini dol etmish".

This verse is not the end of the quadruple, but taken from the last verse of the "etmish" rhythmic ghazal. This last verse was omitted in the "The Anthology of the History of Uzbek Literature" compiled by scientist Sharafiddinov. Also, the speaking person should be Nasriddin Boki, not the Boki. Gafur Ghulam, Habibi, Boki and several other scholars and poets were members of the commission to study the works of Navoiy. They also had a special friendship and a friendly atmosphere.We understand that the Boki teacher, speaking "closing his eyes", was interested in the work of Sultonhoja Ado through his speech, concentrating his ideas on the works of Ado, about "Ado the leader of the scholars of Umarkhan's palace" and his work. 
Or there is an episode in Abdulhamid Cholpon's novel "Kecha va Kunduz (Night and Day). Here's the situation:Miryakub moved his chair closer, and after pouring a thick tea from a beautiful chamomile, he put two candies on the plate. Then he took something out of his bosom and opened it.

- "What is it?" - asked a man.

- Is that what you said in the court?

- Yes, a four-letter verse in Persian. I had shown this to Shahobiddin the teacher and he said that this is the poem of a poet named Ado, who was a judge in the days of Umarkhan, he further commented that this was written by his own hand.

- Well, in that case it cannot be that much old," said the man, getting the manuscript.

- But if it really is a work of a genuine Mawlana Ado, then it is a true blessing. Thank you, Miryakub.

Tura wore his glasses again.

- "Limuharririhu ..." Beautiful letter ... Had that Mawlana Ado been such a good calligrapher? In the East, in the Islamic East, photography could not evolve because religion was banned, but this art of calligraphy was well developed. Well, let's see ... Shall we read through..

«Гул рангли кўз ёшлари ва сарғайган юзлар ажиб гўзал бўладилар, худди зар юргизилган ёқут каби гўзал бўладилар. Сен агар бодом цингари бошдан-оёқ кўздан иборат бўлсанг, хеч нарса кўролмайсан, аммо севги сурмаси

ила очилган кўз равшан бўлади»

(Flowerlike tears and yellowish faces became

stunningly beautiful, they just became like the ornamented rubies with gold stunningly beautiful. If you are like almond-shaped full of eyes throughout your whole body, you cannot see anything, but the eyes which are opened with the image of love can see clear)

- We have never encountered these verses of Mavlono Ado. In this respect as well, this writing has got a good value. explained

- What is the meaning of verse, tura? Tura

- A beautiful poem ... Umarkhan seems to have been a king of a very good temper. He is said to have been a pious man and a poet. His ministers had also been poets. Those who came after him were not ingenious ... How could have Shahobiddin the teacher known that this was from Mawlana Ado?

- There is a judge's seal on the bottom, he said. That is said to be Mewlana Ado ...

- Oh, by the way, there's a seal ... huh ... yes, here: "Qadi Abdillatif ... Sayyid al-Muslumin Amir Umar" ... Marvelous, this has been revealed that the letter is truly a work of the time of Umarkhan. But it cannot Ado who wrote it. Mewlana Ado's name must have been Sultankhan ... I have read. Not Abdillatif. Shahobiddin seems to have made a mistake.
- Your teachers don't know such kind of things well ...

- I do not know, tura. This is what Shahobiddin makhsum said." It really is a good case that the Russian clerk had an interest in Ado. But this is a work of fiction. Hence, the writer of the novel Chulpon had been familiar with the life and work of Sultankhuja Ado. The line reading "We have never encountered this verse of Mavlono Ado" reveals that the author had read ghazals, rhymes and works of the poet in general. Ado is found in a few of the literary studies of the independence period. But we are also surprised that "Soviet thinking" was preserved even in this period. In his book "Adabiyotshunoslikka Kirish (Introduction to Literature) by Erkin Hudoyberdiev, we read: "The Sheikh-ul-Islam Sultanhontura Ahrori (Ado), who spies for the Emir of Bukhara, is seen to be even more superior to Navoiy. He received ten thousand gold awards for equating Amiriy (Umarkhon) with the Baikarah."

We do not know from what sources E. Khudoyberdiev wrote this information. There is no indication of which manuscript or lithograph copy is cited. Even "Tazkirayi Kayumi" mentioned the above verses, and it was regarded as a materialist, as in the "Kukand Adabiy Muhiti," but it was not said that Ado, like Hudoyberdiev, had surpassed Navoiy in his own view and received a so-called reward for him being flatterer.

It would not be wrong to say that this error was corrected in a timely manner. In the article by scholar Aftondil Erkinov, (snoska) it is scientifically proven that the verse has not been adequately analyzed, and sources have proven that Ado's verse was written based on honorary.

An article by the literary critic O.Jurabaev in the issue 28 of the 2009 "O'zbek adabiyoti va san'ati" (Uzbek Literature and Art) newspaper contains information about the manuscript source, which is currently stored at the Azerbaijan Science Academy, that was ordered by Sultonkhan Ado Ahroriy. According to this source, a number of the Navoiy and Fuzuliy's rubais (a type of poem) were written a devoted-rubai by Ado.

From the poet we have received several literary works and his various works in literary heritage.

At present, in the Fund of Manuscripts of the Institute of Oriental Studies of the Academy of Sciences of the Republic of Uzbekistan, there are the divans in the Persian language, numbered 8200 and 4444 and devotions numbered 8280, 4375 and 9014.

According to Qadi Rahmatullah Wozeh's "Tuhfat ul-ahbob", he also had a divan in Turkic language. From this work we also learn that there are many of his poems, and that one of them has a large volume called "Nola va Fig'on (mourning and outcry)

In "The Miroti futuh (Mirror of Victory)" a work about the Kokand khanate is a Russian scientist 
L.A. Zimin described Sultankhuja Ado. This work is not available at present; we have the knowledge of its existence through researchers only.

In our opinion, this work is not a work of Ado. Because of the contents of the book, the events of the book date back till the end of 1898. S. Ado died in 1835-36. In addition, no source says that Ado had a historical work. 